\title{
IMPLEMENTASI PENDIDIKAN KARAKTER BERBASIS LESSON STUDY PADA MATA KULIAH ANALISIS VEKTOR
}

\author{
Edy Suprapto \\ Prodi Pendidikan Matematika IKIP PGRI Madiun \\ E-mail: edypraja@gmail.com
}

\begin{abstract}
Abstrak
Penelitian ini bertujuan untuk: (1) Menghasilkan rumusan nilai-nilai karakter yang perlu ditanamkan dalam implementasi pendidikan karakter pada matakuliah analisis vektor, (2) Menghasilkan rumusan implementasi pendidikan karakter dalam matakuliah analisis vektor berikut perangkatnya, dan (3) Menghasilkan rumusan implementasi pendidikan karakter dalam matakuliah analisis vektor yang efektif.

Penelitian ini termasuk penelitian tindakan kelas dengan desain penelitian menggunakan lesson study yang terdiri dari empat komponen siklus mulai dari tahap perencanaan, pelaksanaan, refleksi dan tindak lanjut. Subjek dalam penelitian ini adalah mahasiswa semester genap kelas VI-B di IKIP PGRI Madiun. Teknik pengumpulan data meliputi metode tes, dokumentasi dan observasi.

Hasil penelitian menunjukkan bahwa: (1) Nilai-nilai karakter yang dapat ditanamkan berkaitan dengan implementasi pendidikan karakter pada matakuliah analisis vektor meliputi: jujur, kerjasama, tanggung jawab dan percaya diri; (2) Implementasi pendidikan karakter pada matakuliah analisis vektor meliputi aspek perencanaan (silabus dan rencana pembelajaran), pelaksanaan (pemilihan metode, sumber belajar, dan media pembelajaran), dan evaluasi pembelajaran (terutama dalam aspek afektif); (3) Integrasi nilai-nilai karakter dalam perkuliahan analisis vektor lebih efektif melalui model kooperatif kolaboratif model diskusi diakhiri dengan presentasi.
\end{abstract}

\section{Kata Kunci: Pendidikan karakter, Analisis Vektor, Lesson Study.}

\section{PENDAHULUAN}

Pendidikan karakter dewasa ini telah menjadi isu nasional yang sering menjadi pembicaraan banyak orang di berbagai kalangan dalam berbagai fora diskusi, seminar dan sarasehan. Banyaknya tindakantindakan menyimpang yang dilakukan pelajar maupun mahasiswa saat ini membuat pendidikan karakter sangat mendesak untuk diterapkan. Pondasi karakter yang kuat, tentunya juga akan menjadikan siswa/mahasiswa mampu bersaing kelak di kancah internasional. Wajah pendidikan Indonesia tercoreng dengan berbagai pemberitaan miring. Sebut saja mulai aksi tawuran, bullying, penyalahgunaan narkotika dan alkohol dikalangan pelajar/mahasiswa dan sebagainya. Fakta yang ada menunjukkan, sudah saatnya pendidikan karakter kembali dimantapkan lewat pendidikan di bangku sekolah atau perkuliahan.

Berkaitan dengan masalah karakter, pemerintah sebenarnya telah berupaya untuk melaksanakan tindakan-tindakan yang bersifat preventif, salah satunya yaitu melalui program pendidikan karakter. Program tersebut memuat beberapa karakter yang perlu dimiliki oleh siswa/mahasiswa, beberapa diantaranya adalah karakter jujur, percaya diri, kerjasama, dan teliti. Hal tersebut juga tercermin di dalam UU Nomor 20 Tahun 2003 tentang Sistem Pendidikan Nasional Pasal 3 yang menyatakan bahwa: Pendidikan Nasional berfungsi mengembangkan kemampuan dan membentuk watak serta peradaban bangsa 
yang bermartabat dalam rangka mencerdaskan kehidupan bangsa, bertujuan untuk berkembangnya potensi peserta didik agar menjadi manusia yang beriman dan bertaqwa kepada Tuhan Yang Maha Esa, berakhlak mulia, sehat, berilmu, cakap, kreatif, mandiri, dan menjadi warga negara yang demokratis serta bertanggung jawab.

Berkaitan dengan masalah karakter, pemerintah sebenarnya telah berupaya untuk melaksanakan tindakan-tindakan yang bersifat preventif, salah satunya yaitu melalui program pendidikan karakter. Program tersebut memuat beberapa karakter yang perlu dimiliki oleh siswa/mahasiswa, beberapa diantaranya adalah karakter jujur, percaya diri, kerjasama, dan teliti. Hal tersebut juga tercermin di dalam UU Nomor 20 Tahun 2003 tentang Sistem Pendidikan Nasional Pasal 3 yang menyatakan bahwa: Pendidikan Nasional berfungsi mengembangkan kemampuan dan membentuk watak serta peradaban bangsa yang bermartabat dalam rangka mencerdaskan kehidupan bangsa, bertujuan untuk berkembangnya potensi peserta didik agar menjadi manusia yang beriman dan bertaqwa kepada Tuhan Yang Maha Esa, berakhlak mulia, sehat, berilmu, cakap, kreatif, mandiri, dan menjadi warga negara yang demokratis serta bertanggung jawab.

Beberapa fakta di lapangan menunjukkan bahwa masih banyak siswa/mahasiswa yang belum sepenuhnya memiliki karakter sesuai dengan apa yang diharapkan tersebut. Salah satu contohnya adalah di Lembaga Pendidikan IKIP PGRI Madiun pada Program Studi Matematika, dimana masih banyak terdapat mahasiswa yang kurang mampu bekerjasama dengan baik ketika mengikuti proses belajar secara berkelompok. Selain itu, rasa kurang percaya diri dan sikap tidak jujur juga masih banyak dijumpai dalam menyelesaikan soal ujian. Di sisi lain, sistem pembelajaran yang dilakukan oleh dosen juga masih cenderung mengabaikan hal-hal yang berkaitan dengan peningkatan kualitas pembelajaran, khususnya terkait dengan upaya-upaya penanaman nilai-nilai karakter pada mahasiswa.

Berdasarkan realita tersebut, ternyata memang tidak semua mahasiswa sudah sepenuhnya memiliki karakter sesuai dengan apa yang diharapkan, diantaranya karakter kerjasama, percaya diri dan jujur. Artinya, sampai saat ini harapan untuk mewujudkan program pendidikan berkarakter masih belum tercapai sepenuhnya. Terlebih lagi hal tersebut juga didukung dengan kurangnya perhatian dosen dalam mengupayakan pembentukan nilai-nilai karakter kepada mahasiswa, diantaranya bentuk kegiatan pembelajaran yang cenderung menggunakan metode ceramah dan sistem pengadaan ujian yang relatif memberikan keleluasaan bagi mahasiswa untuk berbuat tidak jujur. Senada dengan hal tersebut, Suyanto (2001) mengungkapkan bahwa kualitas pendidikan di Indonesia masih sangat rendah tingkat kompetisi dan relevansinya. Begitu pula berdasarkan laporan United Nation Development Program (UNDP) tahun 2005, yang mengungkapkan bahwa kualitas Sumber Daya Manusia (SDM) di Indonesia menempati posisi ke-109 dari 117 negara (Istamar Syamsuri, 2010). Hal itu mengindikasikan bahwa jika kualitas SDM rendah, maka kualitas pendidikan di Indonesia juga relatif masih rendah.

Oleh karena itu, salah satu usaha yang harus ditempuh untuk menanamkan nilainilai karakter pada mahasiswa, khususnya pembelajaran matematika adalah dengan perbaikan dan penyempurnaan proses pendidikan dan semua aspek yang tercakup dalam pembelajaran matematika tersebut. Praktik-praktik pembelajaran matematika dapat diubah melalui pengujian terhadap cara-cara dosen belajar dan mengajar, serta menganalisis dampaknya terhadap perolehan belajar mahasiswa. Agar hal ini dapat 
terwujud, lembaga perlu menciptakan suatu proses yang mampu memfasilitasi para dosen untuk melakukan kajian terhadap materi pembelajaran dan strategi-strategi mengajar secara sistematis, sehingga selain dapat memfasilitasi mahasiswa dalam meningkatkan prestasi belajarnya juga dapat mengupayakan pembentukan nilai-nilai karakter yang diharapkan. Dosen seyogyanya mulai meninggalkan cara-cara rutinitas dalam pembelajaran, tetapi lebih menciptakan program-program pengembangan yang lebih profesional. Upaya tersebut merupakan implikasi dari reformasi pendidikan dengan tujuan agar mampu mencapai peningkatan perolehan belajar mahasiswa secara memadai. Program-program pengembangan profesi dosen tersebut membutuhkan fasilitas yang dapat memberi peluang kepada mereka learning how to learn dan to learn about teaching. Salah satu bentuk fasilitas yang dapat diterapkan adalah melalui lesson study (kaji pembelajaran).

\section{METODE}

\section{Tempat dan Subjek Penelitian}

Tempat pelaksanaan penelitian ini di Program Studi Pendidikan Matematika FPMIPA IKIP PGRI Madiun. Subjek penelitiannya adalah mahasiswa kelas VI-B semester genap tahun ajaran 2011/2012.

\section{Jenis Penelitian}

Jenis penelitian yang digunakan dalam penelitian ini adalah Penelitian Tindakan Kelas (PTK), yaitu suatu penelitian yang bersifat kolaboratif berdasarkan permasalahan yang muncul dalam kegiatan pembelajaran. Desain penelitian adalah lesson study dengan tahapan yang meliputi perencanaan (plan), pelaksanaan $(d o)$, dan evaluasi (see).

\section{Teknik dan Instrumen Pengumpulan Data}

Teknik pengumpulan data dalam penelitian ini meliputi metode tes untuk mengetahui prestasi belajar mahasiswa, dokumentasi untuk mendapatkan catatancatatan penting yang berhubungan dengan masalah pembelajaran, observasi untuk mengadakan pencatatan secara sistematis mengenai tingkah laku secara langsung kelompok ataupun individu terkait dengan karakter yang ditanamkan, dan wawancara digunakan untuk mengungkap data tentang pelaksanaan pembelajaran Analisis Vektor.

HASIL

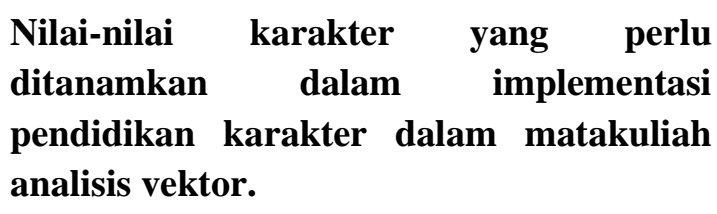

Nilai-nilai karakter yang perlu ditanamkan berkaitan dengan implementasi pendidikan karakter dalam matakuliah analisis vektor berdasarkan diskusi tim peneliti adalah: disiplin, kerjasama, tanggungjawab, jujur dan percaya diri,. Nilai-nilai tersebut tertuang secara eksplisit dalam silabus dan rencana perkuliahan dengan harapan bahwa nilai-nilai tersebut memang direncanakan dan diintegrasikan secara terprogram.

\section{Rumusan implementasi pendidikan karakter dalam matakuliah analisis vektor berikut perangkatnya.}

Integrasi nilai-nilai karakter dalam rencana pelaksanaan pembelajaran dilakukan dengan memasukkan nilai-nilai karakter dalam indikator pencapaian kompetensi aspek afektif yang meliputi:

a. Mahasiswa mengikuti kuliah dengan antusias, tertib dan disiplin,

b. Mahasiswa menyadari pentingnya mempelajari matakuliah analisis vektor,

c. Mahasiswa menghargai pendapat orang lain/teman sendiri dalam berdiskusi kelompok atau kelas,

d. Mahasiswa mampu bekerjasama dalam tim,

e. Mahasiswa memiliki tanggungjawab baik secara individu maupun kelompok,

f. Mahasiswa memiliki rasa percaya diri yang tinggi dengan hasil pekerjaannya, 
g. Mahasiswa mampu bekerja secara jujur dalam mengerjakan soal kuis. Rincian integrasi nilai-nilai karakter dalam

Tabel 1. Integrasi nilai-nilai karakter dalam rencana perkuliahan

\begin{tabular}{l|cccc}
\hline \multirow{2}{*}{\multicolumn{1}{c|}{ Aktivitas }} & \multicolumn{3}{c}{ Karakter yang akan ditanamkan } \\
\cline { 2 - 4 } & Disiplin & Kerjasama & Kejujuran & Percaya diri \\
\hline Kegiatan Pendahuluan & $\sqrt{ }$ & $\sqrt{ }$ & $\sqrt{ }$ \\
Kegiatan Inti & $\sqrt{ }$ & $\sqrt{ }$ & dilakukan melalui variasi metode, sumber \\
Kegiatan Penutup & $\sqrt{c}$ & & belajar, maupun media pembelajaran. Variasi \\
\hline \multicolumn{2}{c}{ Rencana integrasi } & nilai-nilai karakter & metode yang direncanakan dapat disajikan \\
tersebut merupakan pedoman bagi pengajar & dalam Tabel 2. berikut:
\end{tabular}

kegiatan pembelajaran. Integrasi nilai-nilai

karakter dalam proses pembelajaran

rencana perkuliahan dapat disajikan dalam Tabel 1 berikut:

Tabel 2. Matriks metode pembelajaran dengan nilai-nilai karakter

\begin{tabular}{l|ccc}
\hline \multirow{2}{*}{ Metode Perkuliahan } & \multicolumn{3}{c}{ Karakter yang akan ditanamkan } \\
\cline { 2 - 4 } & Disiplin & Kerjasama & Percaya diri \\
\hline Ceramah & $\sqrt{ }$ & $\sqrt{ }$ & $\sqrt{ }$ \\
Diskusi & $\sqrt{ }$ & $\sqrt{ }$ \\
Presentasi & & & $\sqrt{ }$ \\
\hline
\end{tabular}

Matriks metode pembelajaran pada Tabel 2. tersebut merupakan panduan dalam integrasi nilai-nilai karakter dalam proses perkuliahan. Integrasi nilai-nilai karakter dalam evaluasi pembelajaran dilakukan melalui variasi metode evaluasi. Variasi metode evaluasi yang direncanakan dapat disajikan dalam Tabel 3. berikut:

Tabel 3. Matriks metode evaluasi dengan integrasi nilai-nilai karakter

\begin{tabular}{l|cccc}
\hline \multirow{2}{*}{ Evaluasi } & \multicolumn{4}{c}{ Karakter yang akan ditanamkan } \\
\cline { 2 - 5 } & Disiplin & Kerjasama & Kejujuran & Percaya diri \\
\hline Tes & & & $\sqrt{ }$ & $\sqrt{ }$ \\
Tugas & $\sqrt{ }$ & $\sqrt{ }$ & & $\sqrt{ }$ \\
Kelompok & $\sqrt{ }$ & $\sqrt{ }$ & $\sqrt{ }$ & $\sqrt{ }$ \\
Pengamatan & &
\end{tabular}

Integrasi pendidikan karakter dalam perkuliahan membawa konsekuensi kebutuhan perangkat pembelajaran. Dalam hal ini perangkat pembelajaran yang dikembangkan adalah: Silabus, rencana pelaksanaan pembelajaran, media, startegi mengajar, bahan ajar, dan evaluasi.
Rumusan implementasi pendidikan karakter dalam matakuliah analisis vektor yang efektif.

Penanaman nilai-nilai karakter dilakukan melalui penerapan metode kooperatif kolaboratif sebagai berikut: 


\section{SIKLUS-I}

\section{Tindakan Pertama}

\section{1) Perencanaan}

Tahap ini bertujuan untuk menghasilkan rancangan pembelajaran yang diperkirakan mampu menciptakan suasana pembelajaran yang lebih mengaktifkan mahasiswa, artinya mahasiswa dilibatkan secara langsung dalam memahami konsep materi (perkalian vektor) secara mandiri sedangkan dosen lebih berperan sebagai fasilitator dan motivator. Selain itu, dalam pembelajaran ini pula diharapkan akan terbentuk karakter tanggung jawab secara individu maupun kelompok dalam penyelesaian tugas secara berkelompok dan terbentuknya karakter jujur dan percaya diri pada saat mengikuti kuis secara individu. Dalam perencanaannya, dosen secara kolaboratif berbagi ide menyusun rancangan pembelajaran untuk menghasilkan cara-cara pengorganisasian bahan ajar, proses pembelajaran, maupun strategi untuk terciptanya suasana kejujuran pada saat kegiatan kuis. Selain daripada tujuan tersebut, juga perlu diketahui bahwa dalam pembuatan RPP disesuaikan dengan hasil observasi awal, dimana suasana pembelajaran masih terpusat pada dosen (lecture centered), serta masih rendahnya keaktifan dan kemandirian siswa dalam belajar. Adapun beberapa kesepakatan yang dihasilkan pada tahap perencanaan oleh team dosen rumpun matakuliah diantaranya: a) Model pembelajaran yang akan digunakan adalah model Student Teams Achievenment Divisions (STAD); b) Materi pembelajaran yaitu perkalian titik/skalar (dot product); c) Menggunakan Lembar Kerja Mahasiswa (LKM) dalam kegiatan diskusi kelompok; d) Media pembelajaran yang akan digunakan adalah laptop dan LCD; e) Mahasiswa diberikan kuis pada kegiatan akhir pembelajaran.

\section{2) Pelaksanaan}

Tahap ini merupakan penerapan dari kesepakatan yang telah dibuat oleh team dosen rumpun pada tahap perencanaan. Dosen menyampaikan garis besar materi yang akan dipelajari, dan selanjutnya dosen membagi mahasiswa menjadi beberapa kelompok dan menjelaskan aturan pembelajaran pada hari itu. Mahasiswa diberikan LKM untuk dikerjakan secara bertanggung jawab dengan kelompoknya.

Dalam pelaksanaan pembelajaran tampak beberapa mahasiswa antusias dalam mengerjakan soal-soal LKM, namun masih ada beberapa mahasiswa yang masih belum bisa bekerjasama dengan anggota kelompok yang lain. Beberapa mahasiswa tersebut masih terkesan pasif, sehingga kurang banyak terlibat dalam kegiatan kelompok. Selanjutnya dosen memberikan kesempatan mahasiswa untuk mempresentasikan hasil diskusi kelompoknya di depan kelas. Pada kegiatan akhir dosen memberikan kuis yang harus dikerjakan oleh masing-masing mahasiswa secara individu, yang nantinya nilai dari masing-masing individu tersebut akan diakumulasi dengan anggota kelompoknya.

\section{3) Monitoring dan Evaluasi}

Nilai-nilai karakter kerjasama dan tanggung jawab sudah terlihat pada aktivitas pembelajaran kelompok meskipun masih tampak belum maksimal, hal tersebut terlihat dari masih adanya beberapa mahasiswa yang pasif. Ketika pelaksanaan kuis, masih banyak mahasiswa yang tidak jujur dan kurang percaya diri dengan hasil pekerjaannya. Beberapa mahasiswa saling bekerjasama dengan anggota kelompok lain dan kurang percaya diri dengan hasil pekerjaannya sendiri, sehingga mereka kurang mempunyai kesadaran tanggung jawab dengan kelompoknya sendiri.

\section{4) Refleksi dan Tindak Lanjut}


Keterlibatan mahasiswa dalam diskusi kelompok yang dilanjutkan dengan kegiatan presentasi masih tampak belum optimal, sehingga diperlukan desain untuk lebih mengoptimalkan kemampuan mahasiswa dalam hal kerjasama dan keaktifan. Selain itu terkait dengan karakter jujur, tanggung jawab dan rasa percaya diri dalam kegiatan kuis yang juga belum optimal, maka diperlukan pula model pemberian kuis yang lebih mengoptimalkan beberapa karakter tersebut.

\section{$\underline{\text { Tindakan Kedua }}$}

\section{1) Perencanaan}

Pada tahap perencanaan tindakan kedua pada siklus pertama ini, ada beberapa hal yang perlu dimodifikasi dalam RPP berdasarkan refleksi yang dilakukan pada tindakan pertama. Adapun kesepakatan yang telah ditentukan oleh team dosen pada tahap ini diantaranya: a) Model pembelajaran yang akan digunakan adalah model Student Teams Achievenment Divisions (STAD); b) Materi pembelajaran yang telah ditetapkan yaitu fungsi vektor; c) Menggunakan Lembar Kerja Mahasiswa (LKM) dengan jumlah soal yang disesuaikan dengan alokasi waktu yang ada; d) Menggunakan lembar pengamatan karakter mahasiswa; e) Media pembelajaran yang digunakan adalah laptop dan LCD; f) Mahasiswa diberikan kuis pada kegiatan akhir pembelajaran.

\section{2) Pelaksanaan}

Dosen memastikan bahwa mahasiswa sudah berada dalam kelompoknya masingmasing, selanjutnya dosen menyampaikan garis besar materi yang akan dipelajari dan memberikan motivasi kepada mahasiswa terkait dengan penanaman karakter kerjasama, tanggungjawab, percaya diri dan jujur. Mahasiswa diberikan LKM untuk dikerjakan secara bertanggung jawab dengan kelompoknya dan dosen senantiasa mengingatkan untuk dapat saling membantu antar sesama anggota kelompok. Kerjasama dalam kelompok sudah berjalan lebih baik, meskipun masih ada beberapa mahasiswa yang terlihat pasif. Selanjutnya dosen memberikan kesempatan mahasiswa untuk mempresentasikan hasil diskusi kelompoknya di depan kelas.

Pada kegiatan akhir dosen memberikan kuis secara individu, dimana nilai individu tersebut akan diakumulasi dengan anggota kelompoknya dan akan menjadi skor kelompok. Dosen mengumumkan hasil penilaian kelompok berdasarkan nilai kuis dari pertemuan sebelumnya.

\section{3) Monitoring dan Evaluasi}

Mahasiswa masih kesulitan dalam mengerjakan soal-soal LKM. Usaha mahasiswa untuk saling membantu ketika belajar kelompok masih kurang optimal, hal tersebut terlihat dari kesenjangan nilai yang cukup jauh antar anggota dalam beberapa kelompok. Masih terdapat beberapa mahasiswa yang kurang jujur ketika mengikuti kuis, beberapa mahasiswa masih bekerjasama dengan anggota kelompok lain sehingga rasa tanggungjawab terhadap kelompoknya sendiri masih kurang optimal.

\section{4) Refleksi dan Tindak Lanjut}

Dosen senantiasa memberikan motivasi agar dalam pembelajaran kelompok mereka bisa saling membantu dalam memahami materi antara anggota, sehingga pada saat kuis individu, kelompok mereka bisa memperoleh hasil yang maksimal. Selain itu dosen juga senantiasa memberika arahan di pertemuan selanjutnya bahwa hasil pekerjaan kuis akan berpengaruh pada nilai kelompok, artinya jika mereka bekerjasama dengan kelompok lain, secara tidak langsung mereka akan merugikan kelompok mereka sendiri. Hal tersebut dilakukan dengan harapan agar dapat meningkatkan kesadaran mahasiswa terhadap karakter tanggung jawab dan jujur. 
SIKLUS-II

\section{Tindakan Pertama}

\section{1) Perencanaan}

Kelompok-kelompok diskusi yang telah menyelesaikan tugas yang diberikan dosen secara bergantian memberikan penjelasan di depan kelas sesuai dengan hasil diskusi kelompoknya. Sebelumnya dosen telah menunjuk secara acak mahasiswa yang maju, dan sengaja ditunjuk mahasiswa yang selama ini pasif dalam kelompoknya. Hal tersebut bertujuan untuk meningkatkan rasa percaya diri dan aktifitas mahasiswa tersebut dalam kegiatan diskusi dan presentasi. Pada kegiatan akhir mahasiswa diberikan kuis secara individu dan harus dikerjakan secara jujur dan bertanggungjawab.

\section{2) Pelaksanaan}

Dosen memberikan penjelasan mengenai garis besar materi yang dipelajari pada hari itu. Selanjutnya masing-masing kelompok diberikan LKM untuk dikerjakan secara bekerjasama, dan dosen menunjuk secara acak mahasiswa yang selama ini pasif di kelompokknya sebelum kegiatan diskusi dimulai. Hal tersebut dilakukan dengan harapan mahasiswa yang ditunjuk berusaha untuk menggali informasi mengenai bagaimana cara penyelesaian soal kepada teman-temannya yang lain dalam kelompoknya. Selanjutnya mahasiswa diberikankesempatan untuk menjelaskan hasil diskusinya di depan kelas, sementara kelompok yang lain memperhatikan penjelasan tersebut. Hal serupa juga dilakukan untuk tugas-tugas yang lainnya.

Pada kegiatan akhir dosen memberikan kuis dengan memperhatikan upaya-upaya untuk menanamkan karakter jujur, percaya diri dan rasa tanggung jawab setiap mahasiswa dengan kelompoknya, diantaranya dengan cara memberi motivasi, desain soal kuis dan setting tempat duduk yang diupayakan mampu meminimalisir upaya-upaya ketidakjujuran mahasiswa.
Dosen mengumumkan hasil penilaian kelompok berdasarkan nilai kuis dari pertemuan sebelumnya.

\section{3) Monitoring dan Evaluasi}

Mahasiswa yang selama ini terlihat pasif mulai terlihat aktif dalam kegiatan diskusi, meskipun kesadaran itu masih didasari karena beban tugas presentasi yang harus dia laksanakan. Namun hal itu diharapkan mampu membangun kesadaran terhadap mahasiswa tersebut bagaimana cara belajar yang baik dan pentingnya bentuk kerjasama dalam kegiatan diskusi kelompok. Dalam kegiatan presentasi, mahasiswa yang selama ini pasif sudah berupaya menjalankan tugasnya dengan baik, meskipun rasa percaya dirinya masih belum terlihat maksimal. Dari hasil pelaksanaan kuis, sebagian besar mahasiswa sudah terlihat jujur, percaya diri dan mulai menunjukkan rasa tanggungjawabnya dalam menyelesaikan soal kuis.

\section{4) Refleksi dan Tindak Lanjut}

Nilai-nilai karakter yang diharapkan sudah mulai dapat dilatihkan dengan baik, meskipun dalam hal kepercayaan diri dalam kegiatan presentasi masih belum maksimal. Selain itu, kesadaran beberapa mahasiswa terhadap aktivitas diskusi juga masih perlu ditingkatkan, karena pada kegiatan pembelajaran tersebut aktivitas mahasiswa yang pasif memang terlihat meningkat, namun hal itu masih didasari karena mereka dibebani untuk presentasi di depan. Oleh karena itu dosen senantiasa menekankan kembali akan pentingnya kerjasama dalam kelompok untuk saling membantu dalam memahami materi.

\section{$\underline{\text { Tindakan Kedua }}$}

\section{1) Perencanaan}

Hampir sama dengan tindakan pertama, kelompok-kelompok diskusi yang telah menyelesaikan tugas yang diberikan dosen secara bergantian memberikan 
penjelasan di depan kelas sesuai dengan hasil diskusi kelompoknya. Mahasiswa yang diberikan tugas untuk presentasi ke depan dan ditunjuk secara acak setelah kegiatan diskusi berlangsung, hal itu untuk melihat sejauh mana perubahan kesadaran mahasiswa yang selama ini pasih terhadap aktifitas diskusi kelompok. Pada kegiatan akhir mahasiswa diberikan kuis secara individu dan harus dikerjakan secara jujur dan bertanggungjawab.

\section{2) Pelaksanaan}

Dosen memberikan penjelasan mengenai garis besar materi yang dipelajari pada hari itu. Selanjutnya masing-masing kelompok diberikan LKM untuk dikerjakan secara bekerjasama, dan dosen menunjuk secara acak mahasiswa yang selama ini pasif di kelompokknya setelah kegiatan diskusi selesai. Dosen menunjuk secara mahasiswa secara bergantian dan acak, baik yang selama ini terlihat aktif maupun pasif dalam kelompokknya. Pada kegiatan akhir dosen memberikan kuis dengan tetap memperhatikan upaya-upaya untuk menanamkan karakter jujur, percaya diri dan rasa tanggung jawab setiap mahasiswa terhadap dirinya sendiri maupun kelompoknya, diantaranya dengan cara memberi motivasi, desain soal kuis dan setting tempat duduk yang diupayakan mampu meminimalisir upaya-upaya ketidakjujuran mahasiswa.

\section{3) Monitoring dan Evaluasi}

Dari hasil kegiatan diskusi terlihat seluruh mahasiswa bisa lebih aktif dalam bekerjasama dengan kelompoknya. Hal tersebut ditunjukkan dengan kepercayaan diri dan kesiapan mereka (termasuk mahasiswa yang selama ini terlihat pasif) dalam kegiatan presentasi. Pada kegiatan kuis, seluruh mahasiswa sudah terlihat memiliki rasa kejujuran, kepercayaan diri, dan bentuk tanggung jawab yang tinggi terhadap diri sendiri maupun kelompoknya.

\section{4) Refleksi dan Tindak Lanjut}

Dosen senantiasa memberikan motivasi dan arahan kepada mahasiswa mengenai arti pentingnya rasa jujur, percaya diri, kerjasama dan tanggung jawab.

\section{PEMBAHASAN}

Integrasi nilai-nilai karakter dalam proses pembelajaran dapat dilakukan mulai tahap perencanaan pembelajaran, pelaksanaan pembelajaran hinggga evaluasi pembelajaran. Terdapat tiga hal pokok yang penting dipertimbangkan dalam mengintegrasikan nilai-nilai karakter dalam proses pembelajaran. Ketiga hal tersebut mencakup: nilai-nilai karakter yang perlu ditanamkan, model penanaman nilai-nilai karakter, dan pola pembelajaran yang terbukti efektif dalam menanamkan nilai-nilai karakter.

Nlai-nilai karakter yang perlu diintegrasikan dalam pembelajaran analisis vektor tidak dapat dilepaskan dari nilai-nilai yang dibutuhkan mahasiswa ketika mereka terjun di dunia kerja nantinya. Berbagai penelitian menujukkan bahwa nilai-nilai kejurjuran, disiplin, percaya diri, bekerjasama dan tanggungjawab merupakan kemampuankemampuan penting yang harus dimiliki seorang pekerja agar sukses dalam pekerjaannya. Oleh karenanya penanaman nilai-nilai tersebut menjadi sesuatu yang penting untuk dilakukan.

Integrasi nilai-nilai karakter dalam pembelajaran dimulai dari perencanaan pembelajaran, pelaksanaan pembelajaran hingga evaluasi. Dalam hal ini perencanaan pembelajaran merupakan jaminan bahwa nilai-nilai karakter memang didesain untuk ditanamkan, oleh karenanya hal ini perlu dirumuskan secara eksplisit dalam rumusan silabus maupun RPP. RPP matakuliah analisis vektor secara eksplisit telah mencerminkan penanaman nilai-nilai karakter. Hal ini tampak dalam rumusan indikator pencapaian kompetensi, metode 
pembelajaran, maupun media atau sumber belajar yang digunakan.

Penelitian ini telah menemukan bahwa integrasi nilai-nilai karakter dalam proses pembelajaran analisis vektor akan menjadi lebih efektif apabila menggunakan pola kooperatif kolaboratif, dalam hal ini ditunjukkan dalam bentuk diskusi yang diakhiri dengan presentasi. Melalui pola ini terlihat nilai-nilai karakter dapat tumbuh dalam diri mahasiswa. Meskipun demikian, terhadap pola tersebut masih perlu dilakukan kajian terus menerus hingga diperoleh model yang betul-betul efektif dalam meningkatkan karakter dan prestasi belajar mahasiswa.

\section{KESIMPULAN DAN SARAN}

\section{Kesimpulan}

1. Nilai-nilai karakter yang perlu ditanamkan berkaitan dengan implementasi pendidikan karakter dalam matakuliah analisis vektor meliputi: jujur, disiplin, kerjasama, tanggung jawab, dan percaya diri. Nilai-nilai yang dikembangkan tersebut merupakan bagian integral dari kompetensi yang tertuang secara eksplisit dalam indikator pencapaian kompetensi sebagai penanda keberhasilan mahasiswa dalam mencapai standar kompetensi

2. Implementasi pendidikan karakter dalam perkuliahan analisis vektor meliputi aspek perencanaan, pelaksanaan, dan evaluasi pembelajaran. Dalam perencanaan pembelajaran, nilai-nilai karakter tersebut diintegrasikan secara eksplisit dalam silabus dan rencana pembelajaran. Dalam pelaksanaan perkuliahan, integrasi nilainilai karakter tersebut dilakukan melalui pemilihan metode, sumber belajar, dan media pembelajaran. Sedangkan dalam evaluasi pembelajaran, integrasi nilai-nilai karakter diintegrasikan dalam proses penilaian terutama dalam aspek afektif.

3. Integrasi nilai-nilai karakter dalam perkuliahan analisis vektor akan lebih efektif apabila dilaksanakan secara kooperatif kolaboratif dengan model diskusi dan diakhiri dengan presentasi.

\section{Saran}

1. Perlu dilakukan kajian mendalam secara berkelanjutan tentang nilai-nilai karakter yang perlu ditanamkan kepada peserta didik/mahasiswa sebagai bagian utuh dari pencapaian standar kompetensi lulusan

2. Perlu dilakukan upaya kongkrit integrasi nilai-nilai karakter dalam proses perencanaan, pelaksanaan dan evaluasi pembelajaran

3. Perlu dilakukan upaya sosialisasi dan penerapan integrasi nilai-nilai karakter dalam konteks matakuliah yang lebih luas.

\section{DAFTAR PUSTAKA}

Cerbin, B. \& Kopp, B. A Brief Introduction to College Lesson Study. Lesson Study Project. online: http ://www.uwlax.edu/sotl/lsp/index2.ht m. diakses tgl 18 Maret 2012.

Istamar Syamsuri. 2010. Peningkatan Kompetensi Guru Untuk Meningkatkan Minat Siswa Pada Bidang Mipa. Makalah disampaikan dalam Lokakarya MIPAnet 2010, The Indonesian Network of Higher Educations of Mathematics and Nanutal Sciences, tanggal 26-27 Juli 2010, di IPB, Bogor.

Lewis, C. 2004. Does Lesson Study Have a Future in the United States?. Online: http: //www.sowi-online.de / journal / 2004-1/lesson lewis.htm. diakses tgl 18 Juli 2012.

Slamet Mulyana. 2007. Lesson Study (Makalah). Kuningan: LPMPJawa Barat. 
Suyanto. 2001. Formula Pendidikan

Nasional era global. Makalah

disajikan dalam simposium

Pendidikan Nasional dan Munas I

Alumni PPS UM di Malang pada

tanggal 13 Oktober 2001.

UU Nomor 20 Tahun 2003 tentang Sistem

Pendidikan Nasional Pasal 3. 